\title{
SELECTING TREE SPECIES FOR THE RESTORATION OF DEGRADED CONSTRUCTION SITES IN THE UPPER MAHAWELI CATCHMENT
}

\author{
Ranjan Attygalle \\ Enviromment and Forest Conservation Division \\ Mahaweli Authority of Sri Lanka, Polgolla
}

\begin{abstract}
A study is being made of the growth of existing trees on eroding construction sites above the Rantembe dam. The preliminary results reported here suggest that species suitable for planting inclucle Adina cordifolia, Bauhinia raccmosa, Cassia roxburghii, and Pterospermum canescens.
\end{abstract}

\section{Introduction}

The Upper Mahaweli Catchment (UMC) extends into Kandy, Nuwara Eliya, Matale and Badulla Districts. Its total area is about $3110 \mathrm{~km}^{2}$. The 150 - $\mathrm{ml}$ contour which crosses the Mahaweli river at Rantembe is its lower boundary.

The Accelerated Mahaweli Development Programme (AMDP), which was started in the late 1970s, was fully operational in the mid-1980s, with work inprogress on the dams, reservoirs and power stations. In preparation for the work, people were evacuated from the constnuction sites to the downstream development arcas. Some destruction of the vegetation, transformation of the landscape, and degradation of the land - especially in its capacity to support plants - was inevitable.

Some of the places where major headworks were carricd out are Kothmale, Atabage. Victoria. Hakurutale. Adikarigama, Polgolla, Randenigala, and Rantembe. On these sites dams, reservoirs, power stations and a network of roads and bridges were constnucted. using heavy machinery. When the constnction activities ceased in the late 1980s, the sites were left in a dilapidated state. Much carth had been removed. Some unstable slopes, left exposed to the weather. finally collapsed. The frequent movement of heavy machinery has also created compacted. impenetrable hardpan on some sites. Contimuing soil movement aggravates the siltation problems of the reservoirs. Landscape amenity values are also reduced..

Many of the abandoned camp sites, carth removal sitcs. concrete yards, temporary store sites, workshop sites, and quarrics still need restoration. Some of them may require little input. but others need heavy investment to bring them to some kind of normality, fit to be recolonized by plants. The rate at which restoration work can progress will be determined by its economic feasibility and the availability of funds. During the past few years many attempts have been made to replant or reseed these areas, but with little success. 
Some work, including phenological and regeneration studies, has becn done in the vicinity of Rantembe by the Botany Department of the University of Peradeniya. These studies have provided uscful preliminan information for the present sludy.

\section{Objectives}

Human interference has disnupted the interactions in the ecosystem beyond recovery by natural processes within any reasonable time limits. The resilience of the sites was very low. Replanting with tree species is considered to be necessary. This study has been begun in order to facilitate successful planting. It is confined to the following objectives:

- Evaluation of the adaptability of sclected tree species to the environment.

- Determination of suitable sizes for planting stock and for planting pits.

This paper will be concerned only with the first of these objectives.

\section{Description of the study area}

Many degraded sites were available: the one at Rantembe was selected because it already had a serious siltation problem. The amount of sediment brought in by the Uma Oya is much more than the contribution from these sites in the immediate vicinity of the reservoir. but nevertheless the lanter was considered important by the head works division of the Malaweli Authority. In addition this area falls within the Victoria-Randenigala-Rintenbe (VRR) Sanctuary. and habitat improvement is also very importam for this reason.

There are several degraded sites between the Randenigala and Rantembe dams. This area was heavily used when these dams. the new Minipe anicut. and the trans-basin canal were being built, between 1984 and 1990. The complete transformation of the formerly lush green vegetation was inevitable. The nattural vegetation had been dominated by mixed evergreen and semideciduous trees.

The rainfall is uncrenly distributed, with a mean annual range of $9(\%)$ to $1200 \mathrm{~mm}$. Usually Fcbnary to September is a dry period. but occasional showers can occur in May. In June to Angust dry desiceating winds prevail. The local wildlife includes elephants. sambhur, and buffaloes. It is also silid that members of the cat family are present, but they are very rarely seen. The area is rich in bird life. The main factors influencing tree growth are the degraded soil. the climate. fires. and wildlife danage.

The Rantembe dam has becn built just below the point at which the Una Oya meets the Mahaweli Ganga. This is where the boundaries of three districts meet; on the lef bank of the Mahaweli is Kandy District, while on the right bank the Uma Oya scparates the Nuwara Eliya and Badulla Districts. Study plots have been laid out in all three districts (Fig. 1). 


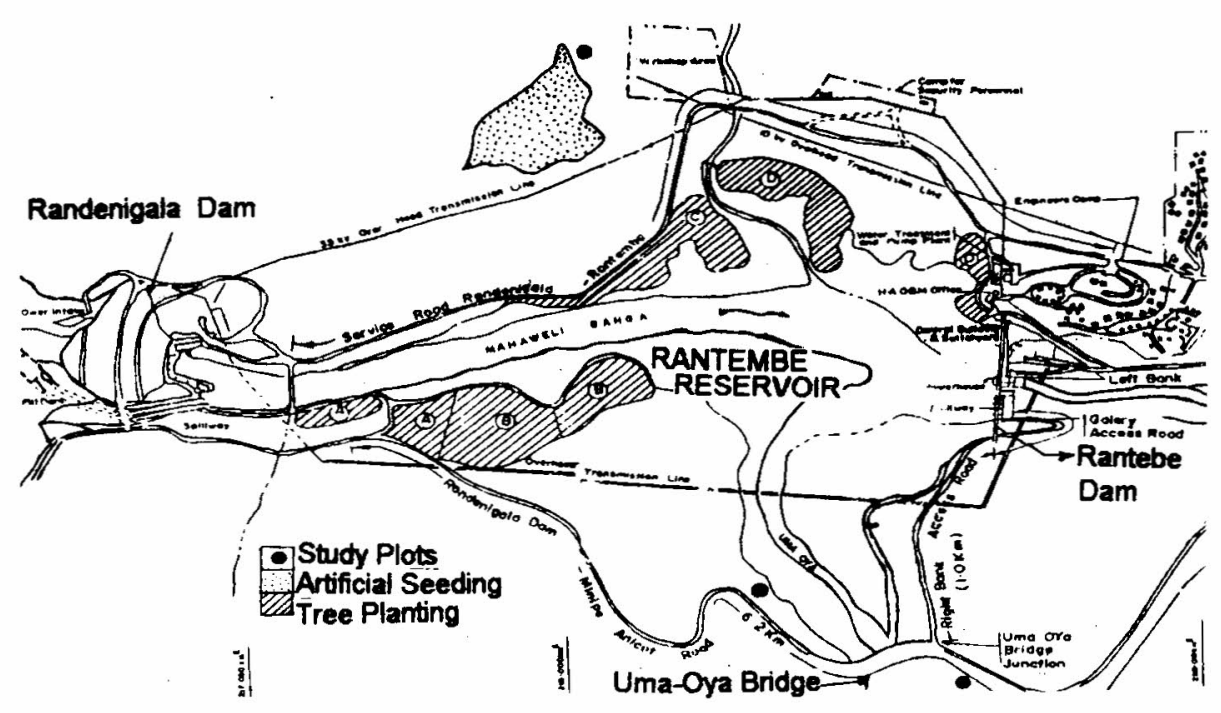

Figure 1 : Location of the study plots in Rantembe

\section{Methodology}

Transect walks were conducted in the selected study area and visual observations were made. These reconnaissance surveys were useful in providing first-hand information about the environment and the species present.

\section{Growth}

Twelve tree species were chosen for study, on the basis of past records and visual observations. Emphasis was given to the food preferences of the local wild herbivores. Three sites were selected, in each of which five individuals from each species were selected and marked with numbered metal tags. Girth at breast height (gbh) was recorded every three months for one year.

\section{Species composition and coppicing ability}

In each of the three sites plots were laid out as follows:

$20 \times 20 \mathrm{~m}$ for trees of $\mathrm{gbh}>15 \mathrm{~cm}$

$5 \times 5 \mathrm{~m}$ for saplings of gbh $<15 \mathrm{~cm}$ and height $>1 \mathrm{~m}$

$1 \times 1 \mathrm{~m}$ for seedlings of height $<1 \mathrm{~m}$

Only the woody plants in each plot were recorded. A record was also made of any species with multiple stems, as an indication of coppicing ability. 


\section{Results and discussion}

\section{Grouth data from individual trees}

Of the twelve species, Albizia odoratissima showed the greatest basal-area increment in absolute terms, and Vitex altissima the least. Cassia roxburghii had the greatest percentage basal-area increment, and (hloroxylon swietenia the least. The species showed similar differences in growth in all three sites. Albizia odoratissima, Grewia daminae, Adina cordifolia. Bridelia retusa, and Cassia roxburghii showed a basal-area increment of more than $50 \mathrm{~cm}^{2}$ during the one-year period. while ('assia roxburghii, Pterospermum canescens, an unidentfied species of the Meliaceae. (irewia daminae, Albizia odoratissima, Terminalia arjuna and Adina cordifolia showed a basal-area increment of more than $20 \%$. Except for (horoxylon swietenia and Vitex altissima all species showed moderate to good growth (Table 1).

Table 1 : Growth data

\begin{tabular}{lcc}
\hline & $\begin{array}{c}\text { Basal-area increment } \\
\left(\mathbf{c m}^{2}\right)\end{array}$ & $\begin{array}{c}\text { Basal-area increment } \\
(\%)\end{array}$ \\
\hline Grewia damincie & 126 & 26 \\
Cassia roxburghii & 59 & 436 \\
Albizia odoratissima & 172 & 15 \\
Tamarindus indicus & 49 & 11 \\
Prerospermum camescens & 19 & 27 \\
Chloroxylon swietenia & 13 & 1 \\
Banhinia racemosa & 43 & 16 \\
Bridelia retusa & 73 & 15 \\
Adina cordifolia & 84 & 20 \\
Unidentitied (Meliaceae) & 31 & 27 \\
Terminalia anjuna & 49 & 22 \\
Vitex altissima & 7 & 3 \\
\hline
\end{tabular}

Plot data on species composition and coppicing ability

Sivteen species were recorded in the $20 \times 20 \mathrm{~m}$ plots, 6 in the $5 \times 5 \mathrm{~m}$ plots and only 2 in the $1 \times 1 \mathrm{~m}$ plots. Table 2 shows the numbers

In the $20 \times 20 \mathrm{~m}$ plots, Pterospermum canescens, Adina cordifolia, and Bauhinia racemosa were the dominant tree species. In the $5 \times 5 \mathrm{~m}$ plots, Bauhinia racemosa and Chloroxylon swietenia were the dominant saplings, and in the $1 \times 1 \mathrm{~m}$ plots Pterospermum canescens was the dominant species anong the seedlings (Table 3 ). 
Table $2:$ Species composition of woody plants in plots

\begin{tabular}{cccc}
\hline Plot size & Plot & No. of species & No. of trees \\
\hline \multirow{2}{*}{$20 \times 20 \mathrm{~m}$} & A & 8 & 19 \\
& B & 3 & 20 \\
\multirow{3}{*}{$5 \times 5 \mathrm{~m}$} & C & 7 & 13 \\
& A & 6 & 16 \\
& B & 5 & 14 \\
$1 \times 1 \mathrm{~m}$ & C & 4 & 6 \\
& A & 0 & 0 \\
& B & 1 & 1 \\
\hline
\end{tabular}

Table 3 :Dominant species in plots

\begin{tabular}{ccl}
\hline Plot size & No. of species & \multicolumn{1}{c}{ Dominant species } \\
\hline $20 \times 20 \mathrm{~m}$ & 16 & $\begin{array}{l}\text { Pterospermum canescens, Adina cordifolia, } \\
\text { Bauhinia racemosa }\end{array}$ \\
$5 \times 5 \mathrm{~m}$ & 6 & Baubinia racemosa, Chloroxylon swietenia \\
$1 \times 1 \mathrm{~m}$ & 2 & Pterospermum canescens \\
\hline
\end{tabular}

Among the sixteen tree species recorded. multiple stems were noted in seven. High frequencies of multiple stems were recorded in Pterospermum canescens, Adina cordifolia and Bauhinia racemosa (Table 4).

Table 4: Tree species with multiple stems

\begin{tabular}{ll}
\hline & Occurrences of multiple stems \\
\hline Pterospermum canescens & 5 \\
Cassia roxburghii & 1 \\
Cassia fistula & 1 \\
Bauhinia racemosa & 3 \\
Adina cordifolia & 4 \\
Unidentified & 1 \\
Unidentified & 2 \\
\hline
\end{tabular}

The occurrence of multiple stems may be due to the elimination of apical dominance, either by browsing by wild animals or by fire. 


\section{Conclusions}

The environmental conditions of the degraded sites at Rantembe necessitate the selection of tree specics which shows promising growth as well as the ability to withstand such hazards as fire and wildlite damage. Thus the ability of a species to coppice. suggested by its producing multiple stems, is an important indicator in selecting species for this site. Provisionally we can say that the following species showed promise:

I'terospermum canescens

Adlina coredifolia

Bauhinia racemosa

('assia roxburghii

Sudics are continuing. 